\title{
I Imagine You Here Now. Relationship Maintenance Strategies in Long-distance Intimate Relationships
}

Iveta Jurkane-Hobein

Uppsala: Uppsala Universitet 2015

72 sider. ISBN: 9789155491611

Anmeldt af Anna Sofie Bach [Ph.D, Sociologisk Institut, Københavns Universitet, aba@soc.ku.dk]

Iveta Jurkane-Hobeins afhandling I imagine you here now. Relationship maintenance in Long-Distance Intimate Relationships giver et interessant indblik i, hvordan parforholdsrelationer og intimitet praktiseres, når geografiske afstande besværliggør regelmæssigt fysisk samvær. Som Jurkane-Hobein også påpeger indledningsvis, er den sociologiske viden om denne type relationer relativt begrænset. Ikke-samlevende par er svære at registre, fordi parret netop ikke har fælles adresse, og har derfor ikke i videre omfang været genstand for den sociologiske familie- og relationsforsknings opmærksomhed. Der ligger dog, som Jurkane-Hobein demonstrerer, meget interessant viden om parintimitet at hente i studiet af disse langdistanceforhold, da intimitetsproducerende praksisser her bliver særligt tydelige, fordi parrelationen ikke indlejrer sig i hverdagslivets trivialitet. Endvidere medvirker øget mobilitet og forandrede migrationsmønstre sammen med nye digitale kommunikationsformer til, at vi i nutidens vestelige samfund formentlig vil se flere og flere par- og familierelationer, der opretholdes på tværs af tid og sted.

Formålet med Jurkane-Hobeins undersøgelse er overordnet set at undersøge, hvordan langdistanceparforhold opleves og fungerer. Hun er således både optaget af de intime praksisser og af de emotionelle strategier, langdistancepar anlægger for at sikre, at kvaliteten og udbyttet af forholdet er så stort, at »det er "værd" at opretholde relationen på tværs geografisk afstand «(s. 61. Min oversættelse. Originale gåseøjne). Studiet tager udgangspunkt i kvalitative interviews med 19 lettiske mænd og kvinder, som er i eller tidligere har været i et parforhold, hvor partnerne bor mere end $45 \mathrm{~km}$ fra hinanden og derfor ikke har mulighed for at se hinanden dagligt. Letland udgør i sig selv en spændende kontekst, idet dette baltiske land, ifølge Jurkane-Hobein, efter at have fået selvstændighed i 1990 har mistet en fjerdel af sin befolkning på grund af emigration. Relativ fattigdom og arbejdsløshed får mange til at søge lykken uden for Letland, hvilket er blevet lettere efter optagelsen i EU og Schengensamarbejdet i 2004. Der er således grund til at antage, at langdistanceforhold, også på tværs af landegrænser, er relativt udbredt fænomen i Letland. Hertil kommer stigningen i antallet af par, der mødes online - en global tendens, der også reflekteres i materialet. 
Afhandlingen er såkaldt artikelafhandling, hvilket betyder, at den består af en længere indledning, som følges af fire videnskabelige artikler, der hver især belyser forskellige aspekter af, hvordan langdistanceparforhold praktiseres og opleves. I den første artikel undersøger Jurkane-Hobein, hvordan sociale normer virker ind på den måde et langdistanceforhold beskrives. Særligt er hun optaget af, hvordan ideer om individualitet, kollektivitet og ikke mindst køn spiller ind på, hvordan relationerne praktiseres. Hun finder således, at de yngre deltagere, som er vokset op efter Sovjetunionens kollaps, i højere grad end de ældre deltagere værdisætter autonomi og selvudvikling, for eksempel $\mathrm{i}$ forhold at forfølge individuelle uddannelses- eller karrieredrømme, selvom det medfører en fysisk adskillelse fra partneren. Blandt de ældre deltagere finder hun derimod mere kollektivistiske og kønstraditionelle værdiorienteringer, som særligt kommer til udtryk i form af par, der affinder sig med, at manden flytter sig for at få et job, hvorigennem han bedre kan forsørge sin kvindelige partner.

I afhandlingens anden artikel fokuserer Jurkane-Hobein på de praksisser, der er medvirkende til at opretholde parintimiteten, når parret ikke er sammen. Hun viser her, hvordan fantasien (imagination) spiller en stor rolle $i$ at vedligeholde oplevelsen af en nærhed. Forskellige sanser stimuleres for skabe følelsen af samvær med den anden. Oplagt er selvfølgelig de utallige telefonsamtaler, hvorigennem den andens stemme bliver tilgængelig, men en deltager fortæller også om, hvordan for eksempel en t-shirt med den andens duft kan fremkalde fornemmelsen af partneren. Jurkane-Hobein udleder i forlængelse heraf et begreb om »forestillet intimitet «, idet paroplevelsen under adskillelsen også opretholdes gennem »indadvendte« og ikke-interaktive praksisser. Det kan for eksempel være at skrive et brev til partneren, føre en dagbog, hvor relationen bearbejdes, eller afskrive sms-beskederne fra kæresten i en notesbog.

I den tredje artikel diskuterer Jurkane-Hobein det »tidsarbejde« (time work), der finder sted i langdistancerelationer. Hun identificerer otte tidsarbejds-strategier, parterne anlægger, for at håndtere relationens temporalitet, når de er henholdsvis sammen og fra hinanden. Artiklen viser, hvordan adskillelsen ofte håndteres ved at fokusere på fremtidige møder og gennem fælles drømme om en fremtid sammen. Centralt er det også, at adskillelsen håndteres ved at fokusere meget på nuet, når parret endelig er sammen, hvilket umiddelbart giver deres samvær en særlig intim og relationsopbyggende kvalitet, som mange andre parforhold formentlig mangler $\mathrm{i}$ det daglige på trods af en rumlig nærhed.

Endelig diskuterer artikel fire, hvordan forestillingen om partneren og parforholdet får betydning for evalueringen af relationen. Jurkane-Hobein er her optaget af, hvorvidt en idealisering af partneren finder sted, netop fordi partnerne ikke er sammen så ofte, og fordi parret derfor i høj grad fokuserer på det positive ved hinanden og deres relation. Samværets ekstra-hverdagslige karakter skaber på den ene side en risiko for at fremtiden byder på skuffelser, når partner pludselig oplever andre sider af hinanden. På den anden side mener Jurkane-Hobein dog også, at idealisering bør forstås som en parforholdsstrategi, der netop er med til at opretholde motivationen for at fortsætte relationen. Forfatteren gør selv opmærksom på, at idealisering kan være svært at måle, 
hvorpå hun i studiet operationaliserer det som et spørgsmål om tilstedeværelsen af positive evalueringer af partneren og relationen kombineret med fraværet af negative udsagn. I den interaktionistiske ramme som afhandlingen skriver sig ind i, mener jeg imidlertid, at denne diskussion savner en komponent af refleksion over, hvordan interviewkonteksten medskaber de fremanalyserede idealiseringsnarrativer. Hvordan spiller interviewpersonens civil-status på interviewtidspunktet for eksempel ind på deres evalueringer? Og hvordan spiller interviewdeltagernes viden om, at forskeren selv har erfaring med langdistanceforhold ind på de fortællinger, der skabes? I hvilket omfang falder idealiseringen af partneren også sammen med ønsket om at fremstille sig selv som en del af en succesfuld kærlighedsrelation og langdistanceforholdet som et tilfredsstillende arrangement?

Samlet set bidrager afhandlingen med en række interessante perspektiver, der udvikler vores forståelse af, hvordan intimitet praktiseres. Særligt bidrager artiklerne til at vise, hvordan nye teknologier muliggør en helt anden form for relationalitet på tværs af tid og rum. Ikke blot skaber internettet nye platforme for pardannelse, det muliggør netop en række relationsopbyggende praksisser, der reducerer betydningen af afstand. Videosamtaler via Skype gør det muligt at se hinanden og sms-beskeder skaber en løbende og konstant kontakt. Selvom afhandlingen tager udgangspunkt i langdistancerelationer, er der således en række perspektiver og begrebsudviklinger, som netop nemt videreføres til andre typer af parrelationer. 